\title{
Functional, textural, physicochemical and sensorial evaluation of cottage cheese standardized with food grade coagulants
}

\author{
Muhammad Bahadur ALI ${ }^{1}$ Mian Shamas MURTAZA ${ }^{1 *}$ (D), Muhammad SHAHBAZ ${ }^{1}$, Aysha SAMEEN ${ }^{2 *}$, \\ Saima RAFIQUE ${ }^{3}$, Rizwan ARSHAD ${ }^{4}$, Nighat RAZA ${ }^{1}$, Zainab AKBAR ${ }^{5}$, Ghazala KAUSAR ${ }^{5}$, Adnan AMJAD ${ }^{6}$
}

\begin{abstract}
Milk is an excellent source of nutrients. It is a balanced diet. Cheeses are fermented milk product. There are hunderds of cheese types. Cottage cheese is fermented dairy product made by the coagulation of milk. It is nutritionally most suitable diet for lactose intolerant people. It contains all essential nutrients. Recently cottage cheese was made with the use of tatri and lemon juice. The use of tatri and lemon do not produce good quality end product. This project was aimed to standardize cottage cheese using food grade coagulants. Cottage cheese was analyzed for physicochemical, textural, functional and sensorial analysis. The use of food grade organic acids produced strong results. The increase in acid level increases the yield but it is not remains good organolaptically. Sensory results reveals that the use of acetic acid has a bitter aftertaste. The use of citric acid at the level of $0.4 \%$ was found best on all aspects.
\end{abstract}

Keywords: Pakistan; livestock; coagulants; tatri and lemon.

Practical Application: Role of coagulants for Cottage cheese production.

\section{Introduction}

Pakistan is an agricultural country. Livestock is a major contributor in this sector after crop production. Livestock includes milk, meat and meat products. Livestock shares $60.5 \%$ shares in agriculture and counted $11.2 \%$ overall share in total GDP of the country. Pakistan ranks among top five milk producing countries of the world. Overall milk production of the country ranges from 57-59 million tons from all sources (Pakistan Bureau of Statistics, 2017).

Milk is an excellent source of nutrition. Milk is considered as compete and balanced diet. It contains all essential nutrients including carbohydrates, fats, protein and all important vitamins and minerals. These bioactive compounds help in regulation of body functions i.e blood pressure regulation, anti-microbial impact and increase in bio-availability of trace elements (Homayouni et al., 2012; Pan et al., 2018).

Cheese is an ancient fermented milk product produced from whole or skim milk. Cheese can be manufactured by the use of rennet (enzyme) and organic acids (citric acid, acetic acid and others). There are more than thousand cheese types available around the globe. Most famous cheese types are Cottage, Cheddar, Mozzarella, Swiss, Edam, Romano, Trappist hand, Brie, Whey, Ricotta and Scoota cheese (Kishor et al., 2017). The variation among all these types depends upon milk source composition of milk, coagulation method, manufacturing process, composition of cheese, ripening time and texture of final product (Rashidinejad et al., 2017).

Cottage cheese is fresh, soft, un-ripened, acid or enzymatic coagulated milk product made from whole or skim milk. Cottage cheese is one of the easiest made cheese types. Commercially cottage cheese was made in 1915 in United States of America. It is produced mostly by the addition of acid and lemon juice. Cottage cheese contains all essential nutrients of milk and is a rich source of protein. There are different types of cottage cheese. These includes dry curd, legal curd, small curd, low fat, non-fat and no salt cottage cheese (Clark \& Potter, 2007).

Cottage cheese can be used as snack, condiment, dessert, stuffing, toppings, salads, and in sandwiches (Walther et al., 2008). Cottage cheese is recommended to diabetic patients due to its low sugar and higher protein contents (Sahu, 2010). Cottage cheese is a best substitute of milk for lactose intolerant people. Cottage cheese is a low caloric cheese type. It is helpful in reduction of obesity and decrease in body weight. The caloric value of cottage cheese is $<418 \mathrm{kj} / 100 \mathrm{~g}$ as compared to cream cheese $1430 \mathrm{kj} / 100 \mathrm{~g}$ and cheddar cheese $1689 \mathrm{kj} / 100 \mathrm{~g}$. 
In past cottage cheese was prepared in Pakistan by the use of lemon and Tatri (Tartaric acid, which is recently banned by Punjab Food Authority, Pakistan). The uncontrolled and nondefined quantity and quality of lemon juice creats physical, chemical and sensory defects in both quality and quantity of final product. This study was aimed at standardization of the procedure for cottage cheese production with different food grade coagulants and quality and functional assessment of cottage cheese during storage.

\section{Materials and methods}

This research was carried out in the laboratories of Department of Food Science and Technology, MNS-university of agriculture, Multan, Pakistan and some of the analysis were performed in the National Institute of Food Science and Technology, University of Agriculture, Faisalabad, Pakistan.

\subsection{Procurement of raw material}

Raw material including milk, food grade organic acids and lemons were purchased from local market of Multan. Fresh milk was collected from farm near to MNS-University of Agriculture Multan. The milk was collected in a stainless steel container. The milk was cooled and brought to the laboratory of Food Science and Technology, MNS-University of Agriculture, Multan Pakistan.

\subsection{Proximate analysis of fresh milk}

Fresh milk was analysed for its basic components i.e moisture (\%), fat (\%), protein (\%). $\mathrm{pH}$, acidity (\%) and ash (\%) content. The assessment of parametrs was done according to standard protocol of Association of Official Analytical Chemists (2000).

\subsection{Manufacturing of cottage cheese}

Cottage cheese was standardized after heating the milk at $85^{\circ} \mathrm{C}$ for 10 minutes and cooling at $70^{\circ} \mathrm{C}$ with some deviations from the standard protocol of Rasheed et al. (2016). After manufacturing cottage cheese was stored in vaccum bags in refrigerated conditions for the period of 28 days.

\subsection{Treatment plan}

Coagulants (Citric acid and acetic acid were used at different concentrations) and explained in the Chart 1.

\section{Quality evaluation of cottage cheese}

Cottage cheese was evaluated for quality attributes during the storage period of 28 days.

\section{Proximate analysis of cottage cheese}

Proximate measures including moisture (\%), fat (\%), protein (\%), $\mathrm{pH}$, and acidity (\%) of cottage cheese was determined by standard protocol of Association of Official Analytical Chemists (2000).
Chart 1. Treatment plan for cottage cheese manufacturing.

\begin{tabular}{cccc}
\hline Treatment & Lemon Juice & Citric Acid & Acetic Acid \\
\hline $\mathrm{T}_{0}$ & Control & - & - \\
$\mathrm{C}_{1}$ & - & $0.3 \%$ & - \\
$\mathrm{C}_{2}$ & - & $0.4 \%$ & - \\
$\mathrm{C}_{3}$ & - & $0.5 \%$ & - \\
$\mathrm{A}_{1}$ & - & - & $0.3 \%$ \\
$\mathrm{~A}_{2}$ & - & - & $0.4 \%$ \\
$\mathrm{~A}_{3}$ & - & - & $0.5 \%$ \\
\hline
\end{tabular}

\section{Texture profile analysis of cottage cheese}

Texture profile (Hardness, cohesiveness, gumminess, springiness and chewiness) of cottage cheese was determined according to standard protocol as described by Brickley et al. (2007).

\section{Functional analysis of cottage cheese}

Melt-ability of cottage cheese was determined by using a tube (glass) with known length and thickness according to standard protocols of Zisu \& Shah (2007).

\section{Coagulation time and yield calculation}

Coagulation time (sec.) and yield percentage of cottage cheese was determined by Spurgeon et al. (1981) and Sipahioglu et al. (1999) respectively.

\section{Sensory evaluation}

Cottage cheese samples were analyzed for sensory attributes using nine point hedonic scale as per the standard protocols of Awad et al. (2004).

\subsection{Statistical analysis}

All the results obtained during the research project were analyzed statistically by the use of complete randomized design (CRD) and Analysis of variance (ANOVA) techniques and evaluation of the consequences of the study was done (Steel \& Torrie, 1997).

\section{Results and discussion}

The present investigation was carried out to evaluate the impact of different coagulants on physico-chemical composition, functional and sensory characteristics of cottage cheese. The results are presented here, with relevant discussion showing their compatibility and incompatibility with the results given by other scientists.

\subsection{Proximate analysis of fresh milk}

Proximate analysis of fresh milk were analysed on the day of collection. The results for different parametrs of fresh milk was found as, moisture $87.53 \pm 1.4 \%$, fat $3.65 \pm 0.31 \%$, 
protein $3.3 \pm 0.61 \%, \mathrm{pH} 6.65 \pm 0.33$, acidity $0.13 \pm 0.06$ and ash $0.72 \pm 0.05$.

\subsection{Physicochemical analysis of cottage cheese}

Proximate analysis of cottage cheese were carried out during the storage period of 0 and $28^{\text {th }}$ day of storage and presented in Table 1. During storage moisture content were found in the range from $47.7 \pm 1.5 \%$ ( $28^{\text {th }}$ day) to $52.28 \pm 1.6 \%$ ( 0 day). There are several reasons for the decrease in moisture content. Basically evaporation process causes the decrease in moisture content of any food commodity but the formation of gel by the use of chemical bound water also causes the reduction in moisture content of cottage cheese during storage. The reduction of hydrated protein also reduces moisture content. Most importantly the biochemical processes and enzymatic activities that are always in process during storage and proceed in the presence of water are the reason for the decrease in moisture content of cottage cheese. Prabhudessai et al. (2014) found the moisture percentage of cottage cheese (53.26\%). The results of this study regarding moisture content are also in accordance with study of Sharma et al. (2018) and Perveen et al. (2011).

The increase in titratable acidity and reduction in $\mathrm{pH}$ of cottage cheese during storage is correlated with each other. The addition of more acid for the production and manufacturing of cottage cheese as per the treatment plan caused the increase in titratable acidity and decrease in $\mathrm{pH}$. The increase in titratable acidity with the increase in storage period is the indication of the increase in number of acid producing bacteria (Al-Kadamany et al., 2002; Afify et al., 2017). Titratable acidity and $\mathrm{pH}$ is highly influenced by lactic acid producing bacteria (Kamleh et al., 2012).

The presence of more bacteria decompose the more biochemical products like lactose and converts it into lactic acid that reduces the $\mathrm{pH}$ and increases the titratable acidity of cottage cheese (Perveen et al., 2011). The results of titratable acidity are in range from $0.76 \pm 0.3 \%$ to $0.97 \pm 0.3 \%$ and $\mathrm{pH}$ ranges from $3.82 \pm 0.8$ to $4.65 \pm 0.9$. El-Owni \& Hamid (2008) showed the increase in titratable acidity of cottage cheese during storage period and results of this study regarding titratable acidity are in accordance with Hordofa (2018). Hamid \& Ismail, 2015 showed the decrease in $\mathrm{pH}$ of cottage cheese during storage and results regarding $\mathrm{pH}$ of cottage cheese are also in accordance with the studies of Tratnik et al. (2001).
Protein is also an important factor and its quality and quantity mainly and highly depends upon the quality and quantity of protein in raw milk. The milk with high protein will yield cheese with high protein percentage (Rasheed et al., 2016). Fat and protein ration in milk also affects the quantity of protein in cheeses (Fox et al., 2017). During stotage percentage protein increases and this could be the attribute of moisture absorption by the curd (Elkhider \& Hamid, 2017).

The increase in protein content during storage is also dependable on fat content of protein. The cheese produced from skim milk has low protein increase during storage as compared to cheese with full fat or added oil during production because the removal of moisture is unable to fill the gaps in curd and thus low fat cheese has less protein increase during storage and vice versa. The highest protein quantity $(20.81 \pm 1.4)$ during the study was found for $\mathrm{C}_{3}$ at $28^{\text {th }}$ day and lowest quantity of protein $(18.50 \pm 1.1 \%)$ was found for $\mathrm{T}_{0}$ on day 0 . The results of this study are in harmony with the studies of both Rasheed et al. (2016) and Hamad \& Ismail (2012). The average mean values for fat content were in rang from $22.06 \pm 1.4 \%$ to $23.59 \pm 0.6 \%$. Fat imparts special qualities in sensory attributes specially in flavor development and mouth feel. These results resemble with the studies of both Rana et al. (2017) and Rulikowska et al. (2013).

\subsection{Coagulation time and yield}

Time required to coagulate milk solid in the form of curd after the addition of acid is termed as coagulation time. Coagulation time is also a temperature dependent factor. The increase in temperature decrease the coagulation time. The high temperature treatment of milk denatures the protein structure, this proteolysis process helps in early coagulation (Ali \& Qazi, 2014). Maximum coagulation time was $21.33 \pm 1.3$ seconds and minimum coagulation time was $5.66 \pm 1.1$ seconds was recorded. Qayyum \& Akhter (2013) showed increase in concentration of acid decreases the coagulation time. The addition of more acid causes coagulation of more milk solids and thus increases the yield. The addition of acid at high temperature also improves the percent yield of cottage cheese (Zeng et al., 2007). Highest cheese yield $19.16 \pm 0.7 \%$ was found for $\mathrm{C}_{3}$ and minimum yield $(18.75 \pm 0.6)$ was obtained for $\mathrm{T}_{0}$. The study of Rasheed et al. (2016) and Karande et al. (2018) verifies the results. The results are elaborated in Table 2.

Table 1. Physicochemical analysis of cottage cheese.

\begin{tabular}{|c|c|c|c|c|c|c|c|c|c|c|}
\hline \multirow{2}{*}{ Treatment } & \multicolumn{2}{|c|}{ Moisture \% } & \multicolumn{2}{|c|}{ Fat $\%$} & \multicolumn{2}{|c|}{ Protein \% } & \multicolumn{2}{|c|}{$\mathrm{pH}$} & \multicolumn{2}{|c|}{ Acidity } \\
\hline & 0 day & $28^{\text {th }}$ Day & 0 day & $28^{\text {th }}$ Day & 0 day & $28^{\text {th }}$ day & 0 day & $28^{\text {th }}$ Day & 0 day & $28^{\text {th }}$ Day \\
\hline $\mathrm{T}_{0}$ & $52.26 \pm 1.6$ & $47.70 \pm 1.3$ & $22.06 \pm 1.4$ & $23.06 \pm 1.2$ & $3.50 \pm 1.1$ & $19.72 \pm 1.3$ & $4.65 \pm 0.8$ & $4.45 \pm 0.9$ & $0.76 \pm 0.3$ & $0.86 \pm 0.2$ \\
\hline $\mathrm{C}_{1}$ & $.96 \pm 1.2$ & $47.53 \pm 1.7$ & $22.09 \pm 1.6$ & $23.45 \pm$ & $3.71 \pm 1.2$ & $19.76 \pm$ & $4.60 \pm 0.3$ & 4.41 & $0.77 \pm 0.2$ & 0.91 \\
\hline $\mathrm{C}_{2}$ & $3 \pm 1.4$ & $47.28 \pm 1.4$ & $7 \pm 1.5$ & $23.44 \pm$ & $89 \pm 1.2$ & $20.10 \pm$ & 4.52 & 4.28 & 0.4 & 0.95 \\
\hline $\mathrm{C}_{3}$ & $52.28 \pm 1.6$ & $47.16 \pm 1.6$ & $22.08 \pm 1.4$ & $23.45 \pm 1.4$ & $19.45 \pm 1.4$ & $20.81 \pm 1.4$ & $4.45 \pm 0.7$ & $3.86 \pm 0.4$ & $0.85 \pm 0.2$ & $0.97 \pm 0.1$ \\
\hline$A_{1}$ & $52.27 \pm 1.4$ & $47.28 \pm 1.4$ & $22.06 \pm 1.2$ & $23.46 \pm 1.1$ & $18.72 \pm 1.2$ & $19.52 \pm 0.7$ & $4.63 \pm 0.5$ & $4.21 \pm 0.5$ & $0.79 \pm 0.4$ & $0.93 \pm 0.4$ \\
\hline $\mathrm{A}_{2}$ & $52.10 \pm 1.2$ & $47.15 \pm 1.7$ & $22.04 \pm 1.3$ & $23.59 \pm 0.6$ & $18.84 \pm 1.1$ & $19.66 \pm 1.0$ & $4.56 \pm 0.9$ & $3.96 \pm 0.6$ & $0.82 \pm 0.6$ & $0.96 \pm 0.5$ \\
\hline $\mathbf{A}_{3}$ & $52.21 \pm 0.9$ & $47.20 \pm 1.3$ & $22.06 \pm 0.5$ & $23.10 \pm 0.6$ & $19.23 \pm 1.3$ & $20.67 \pm 0.5$ & $4.41 \pm 0.4$ & $3.82 \pm 0.7$ & $0.87 \pm 0.3$ & $0.97 \pm 0.3$ \\
\hline
\end{tabular}


Table 2. Texture, coagulation time and yield of cottage cheese.

\begin{tabular}{cccccccc}
\hline Treatment & $\begin{array}{c}\text { Coagulation } \\
\text { Time }\end{array}$ & Yield & Hardness & Cohesiveness & Gumminess & Springiness & Chewiness \\
\hline $\mathbf{T}_{\mathbf{0}}$ & $21.333 \pm 1.3$ & $18.750 \pm 0.6$ & $0.78 \pm 0.62$ & $0.360 \pm 0.2$ & $0.24 \pm 0.06$ & $1.052 \pm 0.3$ & $0.350 \pm 0.4$ \\
$\mathbf{C}_{1}$ & $15.333 \pm 1.6$ & $18.847 \pm 0.4$ & $0.79 \pm 0.11$ & $0.410 \pm 0.4$ & $0.25 \pm 0.03$ & $1.046 \pm 0.2$ & $0.390 \pm 0.5$ \\
$\mathbf{C}_{2}$ & $11.000 \pm 1.3$ & $18.910 \pm 0.2$ & $0.82 \pm 0.82$ & $0.470 \pm 0.7$ & $0.28 \pm 0.07$ & $1.044 \pm 0.7$ & $0.426 \pm 0.2$ \\
$\mathbf{C}_{3}$ & $7.6667 \pm 1.2$ & $19.160 \pm 0.7$ & $0.84 \pm 0.43$ & $0.530 \pm 1.3$ & $0.31 \pm 0.02$ & $1.038 \pm 0.2$ & $0.486 \pm 0.3$ \\
$\mathbf{A}_{1}$ & $13.333 \pm 1.5$ & $18.827 \pm 0.2$ & $0.81 \pm 0.67$ & $0.430 \pm 0.5$ & $0.27 \pm 0.05$ & $1.046 \pm 0.5$ & $0.403 \pm 0.6$ \\
$\mathbf{A}_{2}$ & $9.6667 \pm 1.4$ & $18.907 \pm 0.9$ & $0.84 \pm 0.84$ & $0.453 \pm 0.7$ & $0.29 \pm 0.09$ & $1.043 \pm 0.6$ & $0.486 \pm 0.4$ \\
$\mathbf{A}_{3}$ & $5.6667 \pm 1.1$ & $19.980 \pm 1.4$ & $0.86 \pm 0.93$ & $0.540 \pm 0.4$ & $0.33 \pm 0.03$ & $1.041 \pm 0.4$ & $0.510 \pm 0.5$ \\
\hline
\end{tabular}

\subsection{Texture profile analysis}

Texture is an important quality factor of cottage cheese. Good quality texture cottage cheese is liked by the consumer. Texture is the combination of different parameters and these parameters includes, hardness, cohesiveness, gumminess, springiness and chewiness. The force required for the compression of cheese samples (up to 30\%) of it's original height is termed as hardness. The ratio of area of two compressions in between force and time is designated as cohesiveness (Tunick et al., 2012). Gumminess is the product of both hardness and cohesiveness. Springiness is the level of elasticity of cheese that can be stretched and returns to its original length is called as springiness and chewiness is the sum of both gumminess and springiness.

The cottage cheese samples were analyzed for texture profile analysis of hardness, springiness, gumminess, chewiness and cohesiveness. Texture profile of cottage cheese is the resultant of different factors and these factors includes composition of raw milk, composition of cheese i.e moisture content of cheese, quantity of protein in cheese, fat level of cheese, total solids, manufacturing process either produced by inoculum and enzyme or by direct acidification and most importantly ripening time and conditions (Lucey et al., 2003).

\subsection{Hardness}

According to Koca \& Metin (2004) there is a positive correlation between protein and hardness of cheeses as protein increases the number of force required for its compression increases. The more pores in structure of cheeses causes the more reduction in moisture content by the addition of more acids and during storage also increases the hardness of cottage cheese (Delgado et al., 2011). The highest value of hardness was found for $\mathrm{C}_{3} 0.86 \pm 0.93 \mathrm{~N}$ and lowest value of hardness was found for $\mathrm{T}_{0}$ and that was $0.78 \pm 0.62 \mathrm{~N}$. The results are in accordance with Souza et al. (2016) they showed the values of hardness in between $0.86 \mathrm{~N}$ and $1.28 \mathrm{~N}$ for ricotta cheese during storage. Borba et al. (2014) also found the results of hardness during storage in the range of $1.94 \mathrm{~N}$.

\subsection{Cohesiveness}

Cohesiveness largely depends upon chemical composition of cheese. According to Koca \& Metin (2004) dry matter influence cohesiveness of cheese samples and there is a direct relationship of dry matter and cohesiveness. The increase in treatment increases the protein content and yield also the dry matter increases thus increasing the cohesiveness of cheese. Fat imparts important attributes in texture and smoothness of cottage cheese as fat aggregates in protein matrix (Romeih et al., 2002). There is a negative link between fat and cohesiveness of cheese as increase in fat content of cheese decrease the cohesiveness of cheeses Eroglu et al. (2016). The highest value of cohesiveness was found for $\mathrm{A}_{3}$ and the value was $0.54 \pm 0.4 \mathrm{~N}$ and least value was found for $\mathrm{T}_{0}$ and the value was $0.36 \pm 0.2 \mathrm{~N}$. The results of this study are in accordance with the studies of Dongare et al. (2019) they found the cohesiveness in the range of $0.49 \mathrm{~N}$ to $0.52 \mathrm{~N}$ that are much closer to our studies. The results are also in accordance with the studies of Eroglu et al. (2016) as they showed the results of cohesiveness in range from $0.36 \mathrm{~N}$ to $0.45 \mathrm{~N}$.

\subsection{Gumminess}

Gumminess is the parameter that is the combination of both hardness and cohesiveness (Bourne, 2002), so the factors that affect the hardness and cohesiveness isolated affects the gumminess cumulatively (Goksel et al., 2013). The parameter gumminess depends upon different factors like cheese type, composition of cheese, fat and protein quantity in milk, manufacturing process and ripening process and period. Moisture percentage, fat level, structure of protein matrix and quantity of dry matter largely affects the gumminess of cheeses. The highest value of gumminess was found for $\mathrm{A}_{3}$ and the value was $0.33 \pm 0.03 \mathrm{~N}$ and least value was found for $\mathrm{T}_{0}$ and the value was $0.24 \pm 0.06 \mathrm{~N}$. The results of the study are in accordance with the studies of Souza et al. (2016) they found the level of gumminess in range of $0.29 \mathrm{~N}$ to $0.43 \mathrm{~N}$.

\subsection{Springiness}

The composition of cheese imparts special attribute to texture of cheese. Specially protein and fat have high influence on springiness of cheeses. The decrease in elasticity of protein matrix of protein causes decrease in springiness of cheese (Delgado et al., 2011). The decrease in elasticity of protein matrix in influenced by fat that present in structure of protein (Karaman \& Akalın, 2013). The highest value of springiness was found for $T_{0}$ and the value was $1.052 \pm 0.3 \mathrm{~cm}$ and least value was found for $\mathrm{C}_{3}$ and 
the value was $1.038 \pm 0.2 \mathrm{~cm}$. The results of our studies much resembles with the studies of Zisu \& Shah (2007), they found springiness in range $0.63 \pm 0.4 \mathrm{~cm}$ to $0.74 \pm 0.6 \mathrm{~cm}$. The results of this study also resambles with the results of Dongare et al. (2019).

\subsection{Chewiness}

Chewiness is the force or energy required for mastication before the process of swallowing (Huang et al., 2007). Chewiness is largely depends upon different factors especially type of cheese, manufacturing process and ripening period. Fat content also have a huge impact on chewiness of cheeses. Full fat cheese has low values of chewiness as compared to low fat cheeses or cheeses made from skim milk. The cheese made from starter culture has low values of chewiness as the texture is soft but the cheese made from direct acidification has high chewiness values but the values of chewiness increases with the increase in ripening period (Eroglu et al., 2016). Refrigeration also have positive impact on chewiness of cheeses as refrigerated temperature causes the hardness of protein matrix thus increases the force required for chewiness. The highest value of chewiness was found for $\mathrm{A}_{3}$ and the value was $0.51 \pm 0.5 \mathrm{~N}$ and least value was found for $\mathrm{T}_{0}$ and the value was $0.35 \pm 0.4 \mathrm{~N}$. The results of this study are in accordance with the studies of Singh et al. (2014) and Shashikumar \& Puranik (2012).

\subsection{Functional analysis}

Ability to flow of any commodity is termed as melt-ability. It is an important quality factor that defines the quality of final product. Moisture is main and essential factor that affects the melt-ability in cottage cheese. The evaporation process reduces the moisture and thus decreases the melt-ability. Except moisture, fat is also an important factor for increase and decrease in melt-ability of cottage cheese. The increase and decrease in fat content of cottage cheese causes increase and decrease in melt-ability of cottage cheese respectively (Ko \& Gunasekaran, 2008; Cais-Sokolińska \& Pikul, 2009). During the storage amino acid chain of protein depletes that causes increase in robustness that ultimately reduces the melt-ability of cottage cheese (McSweeney, 2007). The values of melt-ability were in range of $47 \pm 1.8 \mathrm{~mm}$ to $41 \pm 1.5 \mathrm{~mm}$. The highest and lowest values of melt-ability was found for $\mathrm{T}_{0}(47 \pm 1.8 \mathrm{~mm})$ and $\mathrm{C}_{3}(41 \pm 1.5 \mathrm{~mm})$ respectively. The results of this study of melt-ability also resembles with the studies of Cais-Sokolińska \& Pikul (2009) and Ko \& Gunasekaran (2008). The results of melt-ability are represented in Figure 1.

\subsection{Sensory evaluation}

The prepared cottage cheese was evaluated for sensory characteristics of odor, flavor, appearance, texture, after taste and overall acceptability. All the prepared samples were presented to judges to evaluate cottage cheese sample using hedonic scale for which 1 score was for dislike extremely and 9 score was for like extremely. The results regarding sensory attributes are presented in Figure 2. The score for odor of cottage cheese samples ranged from $6.33 \pm 0.4$ to $7.33 \pm 0.6$ and maximum score were gained by $\mathrm{C}_{2}(7.33 \pm 0.6)$. The score for flavor of cottage cheese sample were in range

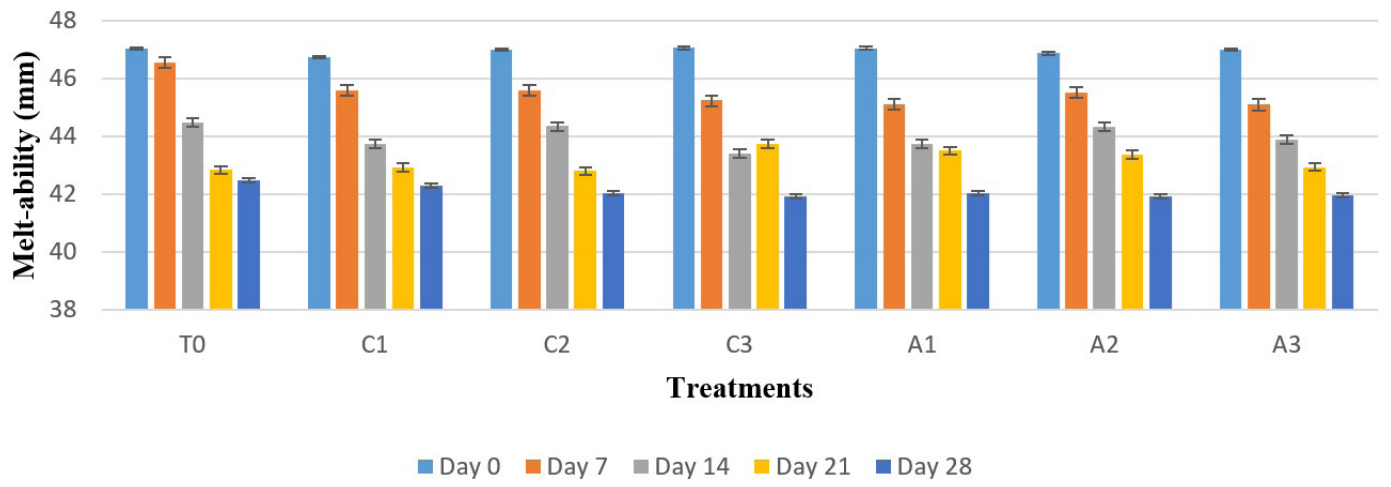

Figure 1. Functional analysis of Cottage Cheese.

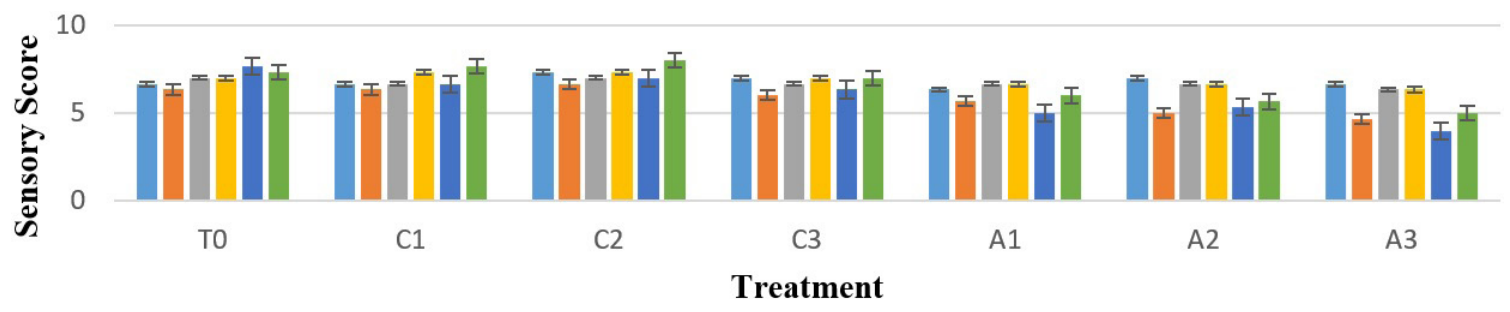

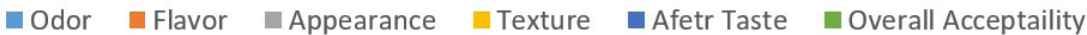

Figure 2. Sensory Evaluation of Cottage Cheese. 
4.66 and 6.66. Minimum score was achieved by $\mathrm{A}_{3}$ score was obtained by $\mathrm{C}_{2}$. Drake et al. (2009) reported the score of flavor (6.1-6.66) that supports our results. The sensory characteristic appearance was counted highest for $\mathrm{C}_{2}(7.00 \pm 0.5)$ and least for A3 $(6.33 \pm 0.4)$. The texture of cottage cheese was same for both $\mathrm{C}_{1}$ and $\mathrm{C}_{2}(7.33 \pm 0.6)$ and the minimum scored were obtained by $\mathrm{A}_{3}(6.33 \pm 0.5)$. The score range for after taste was $7.66 \pm 0.9$ to $4.00 \pm 0.4$ and $\mathrm{T}_{0}$ scored highest $(7.66 \pm 0.7)$ among all samples. The score for texture and after taste 7.5 and 7.8 respectively illustrated by Rasheed et al. (2016) that supports the results of our study. Overall acceptability was maximum for $\mathrm{C}_{2}(8.00 \pm 0.9)$ and lowest for $\mathrm{A}_{3}(5.00 \pm 0.4)$. Hubbard et al. (2016) found the expected results for overall acceptability of cottage cheese in the range of 4.9 to 6.3 but Khatkar et al. (2017) found the results $(8.05 \pm 0.51)$ of overall acceptability of cottage cheese. On the basis of judgment from judges, the cottage cheese prepared from citric acid @ 0.4\% was found best on all aspect of sensory characteristics.

\section{Conclusion}

Cottage cheese was analyzed for physicochemical, textural, functional and sensorial analysis. On the basis of these parameters, use of citric acid at the level of $0.4 \%$ was found best on all aspects. The increase in acid level increases the yield but final product remains not good organolaptically. Sensory results reveals that the use of acetic acid has a bitter aftertaste.

\section{References}

Afify, A. S., Abdalla, A. A., Elsayed, A., Gamuhay, B., Abu-Khadra, A. S., Hassan, M., Ataalla, M., \& Mohamed, A. (2017). Survey on the moisture and ash contents in agricultural commodities in Al-Rass Governorate, Saudi Arabia. Assiut Journal of Agricultural Sciences, 48, 55-62.

Ali, M., \& Qazi, I. M. (2014). Effect of different coagulants on cheese yield and quality prepared from cow milk (Master's thesis). Department of Food Science and Technology, The University of Agriculture, Peshawar.

Al-Kadamany, E., Toufeili, I., Khattar, M., Abou-Jawdeh, Y., Harakeh, S., \& Haddad, T. (2002). Determination of shelf life of concentrated yogurt (Labneh) produced by in-bag straining of set yogurt using hazard analysis. Journal of Dairy Science, 85(5), 1023-1030. http:// dx.doi.org/10.3168/jds.S0022-0302(02)74162-3. PMid:12086035.

Association of Official Analytical Chemists - AOAC. (2000). Official methods of analysis (17th ed., pp. 802-840). Washington: AOAC.

Awad, R. A., Abdel-Hamid, L. B., El-Shabrawy, S. A., \& Singh, R. K. (2004). Physical and sensory properties of block processed cheese with formulated emulsifying salt mixtures. International Journal of Food Properties, 7(3), 429-448. http://dx.doi.org/10.1081/JFP-200032934.

Borba, K. K. S., Silva, F. A., Madruga, M. S., Queiroga, R. C. R., Souza, E. L., \& Magnani, M. (2014). The effect of storage on nutritional, textural and sensory characteristics of creamy ricotta made from whey as well as cow's milk and goat's milk. International Journal of Food Science \& Technology, 49(5), 1279-1286. http://dx.doi.org/10.1111/ijfs.12432.

Bourne, M. C. (2002). Physics and texture. In M. C. Bourne (Ed.), Food texture and viscosity: concept and measurement (2nd ed., pp. 59-106). San Diego: Academic. http://dx.doi.org/10.1016/B978-012119062-0/50003-6.

Brickley, C. A., Auty, M. A. E., Piraino, P., \& McSweeney, P. L. H. (2007). The effect of natural cheddar cheese ripening on the functional and textural properties of the processed cheese manufactured therefrom. Journal of Food Science, 72(9), C483-C490. http://dx.doi. org/10.1111/j.1750-3841.2007.00539.x. PMid:18034708.

Cais-Sokolińska, D., \& Pikul, J. (2009). Cheese meltability as assessed by the tube test and schreiber test depending on fat contents and storage time, based on curd-ripened fried cheese. Czech Journal of Food Sciences, 27(5), 301-308. http://dx.doi.org/10.17221/223/2008-CJFS.

Clark, S., \& Potter, D. E. (2007). Cottage cheese. In Y. H. Hui (Ed.), Handbook offood products manufacturing (pp. 617-633). Hoboken: John Wiley \& Sons. http://dx.doi.org/10.1002/9780470113554.ch26.

Delgado, J. F., Gonzalez-Crespo, J., Cava, R., \& Ramirez, R. (2011). Proteolysis, texture and colour of a raw goat milk cheese throughout the maturation. European Food Research and Technology, 233(3), 483-488. http://dx.doi.org/10.1007/s00217-011-1536-3.

Dongare, S. A., Dige, Y. P., \& Syed, H. M. (2019). Storage study and textural profile analysis of paneer at different temperature. Journal of Pharmacognosy and Phytochemistry, 8, 864-868.

Drake, S. L., Lopetcharat, K., \& Drake, M. A. (2009). Comparison of two methods to explore consumer preferences for cottage cheese. Journal of Dairy Science, 92(12), 5883-5897. http://dx.doi.org/10.3168/ jds.2009-2389. PMid:19923592.

Elkhider, I. E. A., \& Hamid, O. I. A. (2017). Physicochemical and sensory characteristics of sudanese lowfat cheese during storage period. Journal of Agriculture and Veterinary Science, 10, 6-10.

El-Owni, A. O. O., \& Hamid, I. A. O. (2008). Effect of storage period on weight loss, chemical composition, microbiological and sensory characteristics of Sudanese white cheese. Pakistan Journal of Nutrition, 7, 75-80.

Eroglu, A., Toker, O. S., \& Dogan, M. (2016). Changes in the texture, physicochemical properties and volatile compound profiles of fresh kashar cheese ( $<90$ Days) during ripening. International Journal of Dairy Technology, 69(2), 243-253. http://dx.doi.org/10.1111/1471-0307.12250.

Fox, P. F., Guinee, T. P., Cogan, T. M., \& McSweeney, P. L. H. (2017). Factors that affect cheese quality. In P. F. Fox, T. P. Guinee, T. M. Cogan \& P. L. H. McSweeney (Eds.), Fundamentals of cheese science (pp. 617-641). Boston: Springer. http://dx.doi.org/10.1007/978-14899-7681-9_15.

Goksel, M., Dogan, M., Toker, O. S., Ozgen, S., Sarioglu, K., \& Oral, R. A. (2013). The effect of starch concentration and temperature on grape molasses: rheological and textural properties. Food and Bioprocess Technology, 6(1), 259-271. http://dx.doi.org/10.1007/ s11947-011-0705-5.

Hamad, M. N., \& Ismail, M. M. (2012). Quality of soft cheese made with Goat's milk as affected with the addition of certain essences. Journal of Animal Production Advances, 2, 121-127.

Homayouni, A., Alizadeh, M., Alikhah, H., \& Zijah, V. (2012). Functional dairy probiotic food development: trends, concepts, and products. In E. Rigobelo (Ed.), Probiotics (pp. 197-212). London: IntechOpen. http://dx.doi.org/10.5772/48797.

Hordofa, B. B. (2018). Acidification process and properties of soft cheese made from cow milk using different starter cultures. African Journal of Food Science and Technology, 9(02), 12-18. http://dx.doi. org/10.14303/ajfst.2018.229.

Huang, M., Kennedy, J. F., Li, B., Xu, X., \& Xie, B. J. (2007). Characters of rice starch gel modified by gellan, carrageenan, and gluco-mannan: a texture profile analysis study. Carbohydrate Polymers, 69(3), 411418. http://dx.doi.org/10.1016/j.carbpol.2006.12.025.

Hubbard, E. M., Jervis, S. M., \& Drake, M. A. (2016). The effect of extrinsic attributes on liking of cottage cheese. Journal of Dairy Science, 99(1), 183-193. http://dx.doi.org/10.3168/jds.2015-9547. PMid:26519972.

Kamleh, R., Toufeili, I., Ajib, R., Kanso, B., \& Haddad, J. (2012). Estimation of the shelf-life of Halloumi cheese using survival 
analysis. Czech Journal of Food Sciences, 30(6), 512-519. http:// dx.doi.org/10.17221/233/2011-CJFS.

Karaman, A. D., \& Akalın, A. S. (2013). Improving quality characteristics of reduced and low fat Turkish white cheeses using homogenized cream. Lebensmittel-Wissenschaft + Technologie, 50(2), 503-510. http://dx.doi.org/10.1016/j.lwt.2012.08.017.

Karande, A. A., Patil, V. N., Raskar, A. B., Joshi, S. V., Dandekar, V. S., \& Desai, B. G. (2018). Effect of different coagulant on yield of paneer. Indian Journal of Pure \& Applied Biosciences, 6(1), 1096-1101. http:// dx.doi.org/10.18782/2320-7051.6125.

Khatkar, A. B., Ray, A., \& Kaur, A. (2017). Studies on shelf life extension of paneer with the addition of plant essential oil and different packaging materials. International Journal of Current Microbiology and Applied Sciences, 6(9), 376-389. http://dx.doi.org/10.20546/ ijcmas.2017.609.047.

Kishor, K., David, J., Tiwari, S., Wilson, I., \& Shankar, B. (2017). Development of nutritive biscuits fortified with different level of chick pea milk cottage cheese. Pharma Innovation, 6(7), 890-892.

Ko, S., \& Gunasekaran, S. (2008). Analysis of cheese melt profile using inverse-Hill function. Journal of Food Engineering, 87(2), 266-273. http://dx.doi.org/10.1016/j.jfoodeng.2007.12.002.

Koca, N., \& Metin, M. (2004). Textural, melting and sensory properties of low-fat fresh kashar cheeses produced by using fat replacers. International Dairy Journal, 14(4), 365-373. http://dx.doi.org/10.1016/j. idairyj.2003.08.006.

Lucey, J. A., Johnson, M. E., \& Horne, D. S. (2003). Perspectives on the basis of the rheology and texture properties of cheese. Journal of Dairy Science, 86(9), 2725-2743. http://dx.doi.org/10.3168/jds. S0022-0302(03)73869-7. PMid:14507008.

McSweeney, P. L. H. (2007). The flavour of milk and dairy products: III. Cheese: taste. International Journal of Dairy Technology, 50(4), 123-128. http://dx.doi.org/10.1111/j.1471-0307.1997.tb01752.x.

Pakistan Bureau of Statistics. Ministry of National Food Security and Research. (2017). Pakistan economic survey 2016-17. Islamabad.

Pan, L., Yu, J., Mi, Z., Mo, L., Jin, H., Yao, C., Ren, D., \& Menghe, B. (2018). A metabolomics approach uncovers differences between traditional and commercial dairy products in buryatia (Russian Federation). Molecules, 23(4), 735. http://dx.doi.org/10.3390/ molecules23040735. PMid:29565828.

Perveen, K., Alabdulkarim, B., \& Arzoo, S. (2011). Effect of temperature on shelf life, chemical and microbial properties of cream cheese. African Journal of Biotechnology, 10, 16924-16928.

Prabhudessai, V., Salgaonkar, B., Braganca, J., \& Mutnuri, S. (2014). Pretreatment of cottage cheese to enhance biogas production. BioMed Research International, 2014, 374562. http://dx.doi. org/10.1155/2014/374562. PMid:24995288.

Qayyum, W., \& Akhter, S. (2013). Comparative efficiency of different coagulants on cottage cheese quality prepared from cow and buffalo milk (Master's thesis). Department of Livestock Management and Animal Breeding and Genetics, The University of Agriculture, Peshawar.

Rana, M. S., Hoque, M. R., Rahman, M. O., Habib, R., \& Siddiki, M. S. R. (2017). Papaya (Carica papaya) latex- an alternative to rennet for cottage cheese preparation. Journal of Advanced Veterinary and Animal Research, 4(3), 249-254. http://dx.doi.org/10.5455/javar.2017.d218.

Rasheed, S., Qazi, I. M., Ahmed, I., Durrani, Y., \& Azmat, Z. (2016). Comparative study of cottage cheese prepared from various sources of milk. Proceedings of the Pakistan Academy of Sciences, 53(4), 269-282.

Rashidinejad, A., Bremer, P., Birch, J., \& Oey, I. (2017). Nutrients in cheese and the effect on health and disease. In R. R. Watson, R. J. Collier \& V. R. Preedy (Eds.), Nutrients in dairy and their implications on health and disease (pp. 177-189). London: Academic Press. http:// dx.doi.org/10.1016/B978-0-12-809762-5.00014-0.

Romeih, E., Michaelidou, A., Biliaderis, C. G., \& Zerfiridis, G. K. (2002). Low-fat white-brined cheese made from bovine milk and two commercial fat mimetics: chemical, physical and sensory attributes. International Dairy Journal, 12(6), 525-540. http://dx.doi. org/10.1016/S0958-6946(02)00043-2.

Rulikowska, A., Kilcawley, K. N., Doolan, I. A., Alonso-Gomez, M., Nongonierma, A. B., Hannon, J. A., \& Wilkinson, M. G. (2013). The impact of reduced sodium chloride content on Cheddar cheese quality. International Dairy Journal, 28(2), 45-55. http://dx.doi. org/10.1016/j.idairyj.2012.08.007.

Sahu, J. K. (2010). Coagulation kinetics of high pressure treated acidified milk gel for preparation chhana (an Indian soft cottage cheese). International Journal of Food Properties, 13(5), 1054-1065. http:// dx.doi.org/10.1080/10942910902950542.

Sharma, S., Vaidya, D., \& Chauhan, N. (2018). Microbiological analysis and nutritional evaluation of cottage cheese produced with kiwifruit enzyme. International Journal of Current Microbiology and Applied Sciences, 7(2), 1-7. http://dx.doi.org/10.20546/ijcmas.2018.702.001.

Shashikumar, C. S. S., \& Puranik, D. B. (2012). Study on use of lactoferrin for the biopreservation of paneer. Tropical Agricultural Research, 23(1), 70-76. http://dx.doi.org/10.4038/tar.v23i1.4633.

Singh, R. R., Singh, R., \& Shakya, B. R. (2014). Impact of turmeric addition on the properties of paneer, prepared from different types of milk. International Journal of Current Engineering and Technology, 4, 1-10.

Sipahioglu, O., Alvarez, V. B., \& Solano-Lopez, C. (1999). Structure, physico-chemical and sensory properties of feta cheese made with tapioca starch and lecithin as fat mimetics. International Dairy Journal, 9(11), 783-789. http://dx.doi.org/10.1016/S0958-6946(99)00150-8.

Souza, J. L. F., Silva, M. A. P., Silva, R. C. F., Carmo, R. M., Souza, R. G., Célia, J. A., Oliveira, K. B., Plácido, G. R., Lage, M. E., \& Nicolau, E. S. (2016). Effect of whey storage on physicochemical properties, microstructure and texture profile of ricotta cheese. African Journal of Biotechnology, 15(47), 2649-2658. http://dx.doi.org/10.5897/ AJB2016.15692.

Spurgeon, K. R., Yee, J. J., \& Martin, J. H. (1981). Selection of milk for maximum yield of cheese and other dairy products. Cultured Dairy Products Journals, 16, 5-11.

Steel, R. G. D., \& Torrie, J. H. (1997). Principles and procedures of statistics: a bio-metrical approach (2nd ed., pp. 137-175). New York: McGraw Hill.

Tratnik, L., Božanić, R., Mioković, G., \& Šubarić, D. (2001). Optimization of manufacture and quality of Cottage cheese. Food Technology and Biotechnology, 39, 43-48.

Tunick, M. H., van Hekken, D. L., Iandola, S., \& Tomasula, P. M. (2012). Characterization of queso fresco during storage at 4 and $10^{\circ} \mathrm{C}$. Journal of Food Research, 1, 308-319. http://dx.doi.org/10.5539/jfr.v1n1p308.

Walther, B., Schmid, A., Sieber, R., \& Wehrmüller, K. (2008). Cheese in nutrition and health. Dairy Science \& Technology, 88(4-5), 389-405. http://dx.doi.org/10.1051/dst:2008012.

Zeng, S. S., Soryal, K., Fekadu, B., Bah, B., \& Popham, T. (2007). Predictive formulae for goat cheese yield based on milk composition. Small Ruminant Research, 69(1-3), 180-186. http://dx.doi.org/10.1016/j. smallrumres.2006.01.007.

Zisu, B., \& Shah, N. P. (2007). Texture characteristics and pizza bake properties of low fat Mozzarella cheeses as influenced by pre acidification with citric acid and use of encapsulated and ropy exo-polysaccharide producing culture. International Dairy Journal, 17(8), 985-999. http://dx.doi.org/10.1016/j.idairyj.2006.10.007. 